\title{
Mini-Project Based Approach to Promote Entrepreneurship and Innovationin Engineering Education
}

\author{
M C Padma ${ }^{1}$, V Sridhar ${ }^{2}$ \\ ${ }^{1}$ Department of Computer Science and Engineering \\ ${ }^{2}$ Department of Electronics and Communication Engineering \\ PES College of Engineering, Mandya, Karnataka, India \\ 1padmapes@gmail.com,2venusridhar@yahoo.com
}

Keywords: Entre preneurship; Innovation; Entrepreneur; Engineering Education; Critical Thinking; Mini-project

\section{Introduction}

Engineering institutions are considered to be the main sources of producing best engineering professionals through quality technical education. Engineering professionals are the most significant resources for the progress of any Nation as they further lead the Nation grows technologically and socio economically. Because of this reason, there is a great demand for quality technical education from engineering institutions.

The continuousmodifications in the field of information technology present both challenges and opportunities to the engineering education. In order to meet these challenges, it is necessary to change the practice of engineering with the globalization of industrial, research and development. Hence it is necessary to encourage many engineering schools to offer entrepreneurship education to their students. Economic trends and changes in the way employers

\section{C Padma}

Department of Computer Science and Engineering PES College of Engineering, Mandya, Karnataka, India padmapes@gmail.com 
organize and make decisions have led to an increased awareness of the potential value of entrepreneurship education to engineering students. To prepare students for this new reality, universities are moving towards creating awareness to graduate engineers who not only understand science and technology, but who can also able to identify opportunities, understand market forces, commercialize new products, and have the leadership and communication skills to advocate for them.

Entrepreneurship has become a key in building prosperity and developing the economy of a Nation. In the current economic context, starting a business is considered to be the best solution to overcome the problem of unemployment. Promoting entrepreneurship among the students has become a key for engineering colleges. Because, students think that it is an alternate towards their job and build their own destiny by starting up their own venture without waiting for a job. Promoting entrepreneurship among the engineering graduates helps in reducing employment. Hence, most of the engineering programs are making an attempt to include entrepreneurship and innovation in the engineering curriculum.

Entrepreneurship refers to the functions performed by an entrepreneur in establishing an enterprise. It is the process of creating something new and assuming the risks and rewards.Creativity is thinking new things, and innovation is doing new things. Creativity is the ability to develop new ideas and to discover new ways of looking at problems and opportunities. Innovation is the ability to apply creative solutions to those problems and opportunities in order to enhance people's lives or to enrich society. Hence, entrepreneurship is considered to be the combination of creativity and innovation.

Industry and society depend on engineers for the design and production of goods that meet customer needs and are safe, reliable, efficient, and competitive in the global market. Furthermore, although colleges and universities produce technically competent graduates who understand engineering concepts and demonstrate the ability to apply them in the real world, they often lack soft skills which enable them to express their full potential. Hence, modern engineers need to be not only technically strong but also creative and able to work well in teams, communicate effectively, and create products that are useful in the "real world." Industry, society, and engineering institutes should work together to guarantee that such qualified and capable engineers are produced to meet industry and society needs.

Innovation and entrepreneurship are the most important aspects to create jobs around the globe. So, it is necessary to educate engineers in an innovative manner and promote entrepreneurship by fundamentally changing the teaching-learning process and curriculum. In addition, some engineering courses like leadership and engineering management can help students develop highly desired attributes that contribute to career and industry success. It is observed that students who have studied entrepreneurship courses gain insights in designing for end users, working in and managing interdisciplinary teams, communicating effectively, thinking critically, understanding business basics, and solving open-ended problems. Hence, it is the responsibility of engineering educators to teach their students to be more innovative and entrepreneurial.

In this study, an effort has been made to identify different factors which are making an impact on the students towards entrepreneurship and innovation. This paper deals with measuring the innovative pedagogy in teaching entrepreneurship to engineering graduates and an attempt is made to identify the different ways to encourage entrepreneurship and innovation. Also, a case study of a set of students who have made an attempt towards the development of a system using the knowledge of innovation and entrepreneurship is presented.

This paper is organized as follows. In Section II, literature work related to entrepreneurship is presented. Factors that influence entrepreneurship in engineering education are presented in Section III. In Section IV, method of promoting engineering students to become entrepreneurs through mini-project based learning is explained. Results and discussions are presented in Section V. Conclusions are given in Section VI.

\section{Literature Review}

Traditionally, majority of the courses on entrepreneurship are included in business or management schools. However, since the last decade many educational institutions have started introducing entrepreneurial education in the engineering curriculum. By now, most of the engineering colleges offer at least one entrepreneurial course. 
Entrepreneurship is becoming more and more acknowledged as an important driver of growth, innovation and job creation [1]. Creativity is usually defined as a combination of novelty and appropriateness and has been associated with problem-solving and novelty generation as well as with reactive and adaptive behaviour that allows people to handle with turbulent environments. Entrepreneurship and innovative business behaviour have long been associated with creativity. Methodologically, creativity in entrepreneurship and innovation has been explained through cognitive processes, attitudes, motivation, existing knowledge, work environment and personality traits [1].

Engineering students appear to be very well suited to become entrepreneurs. In paper [2], authors have summarized data related to engineering student interest and involvement in entrepreneurship education, attitudes toward entrepreneurship as a career option, how this involvement relates to students' entrepreneurial self-efficacy, and the characteristics of students who participate in these courses and programs [2]. It is observed from this study that those who took one or more courses were found to have significantly higher entrepreneurial self-efficacy than those who did not.

Economic realities such as global competition, downsizing, decentralization, re-engineering, mergers, and new technologies have made career paths more complex and uncertain for graduates in all sectors [3]. In this new environment, it is widely accepted that entrepreneurial ventures are key to innovation and economic growth. Therefore, students who are able to identify opportunities, understand market forces, commercialize new products, communicate, and lead teams, in addition to having strong science and technical skills, are likely to have more value in the market place for jobs. The Engineering Entrepreneurship Survey (EES) can be an effective tool as universities and departments develop entrepreneurship courses and programs for engineering students. The literature review on which it is based can serve as a resource for researchers developing assessment instruments in the field of entrepreneurship education. So far, it has been used effectively to detect differences across groups of students who have and who have not been exposed to entrepreneurship education. In paper [3] authors have described the development, use, and preliminary validation of the Engineering Entrepreneurship Survey (EES). This survey instrument has been used successfully to collect data among engineering students enrolled at universities that have entrepreneurship programs accessible to engineering students.

Changes in the economy and workforce needs have driven many engineering schools to consider offering entrepreneurship education to their students. In paper [4], authors have explored a broad array of attitudes toward and outcomes of entrepreneurship education on engineering students in order to understand the characteristics of students participating in related courses and activities, the nature and extent of their involvement, entrepreneurship's role in their career plans, and its impact on entrepreneurial self-efficacy [4].

Economic trends and changes in the way employers organize and make decisions have led to an increased awareness of the potential value of entrepreneurship education to engineering students [5]. Today, a glamorous job for an engineer might be to work in a smaller, more entrepreneurial company, which requires 'a broad range of skills and knowledge beyond a strong science and engineering background' [6]. To prepare students for this new reality, universities are increasingly aware that they must graduate engineers who not only understand science and technology, but who are also able to identify opportunities, understand market forces, commercialize new products, and have the leadership and communication skills to advocate for them. This has prompted a significant increase in the delivery of entrepreneurship education to engineering students through new courses, programs, and experiential learning opportunities, support from professional organizations such as the National Academy of Engineering (NAE) and the American Society for Engineering Education(ASEE) [7].

\section{Factors That Influence Entrepreneurship}

It is observed from the feedback from most of the engineering institutes that the percentage of graduates getting into entrepreneurship field is relatively less, even though there is continuous support and assistance from the authorized and supporting bodies [2]. Entrepreneurship is slowly picking in India since engineering graduates are not showing much interest towards entrepreneurship. It is necessary to figure out and address the factors which are resulting in poor rate of entrepreneurship among engineering graduates. This in turn leads to identify the positive factors that 
of entrepreneurship among engineering graduates. This in turn leads to identify the positive factors that can be used to motivate and create entrepreneurial interest among the engineering graduates. Major factors chosen for consideration to create interest and develop confidence to engineering graduates are (i) Determination to become an entrepreneur; (ii) Desire and willingness towards entrepreneurship; (iii) Hard work and Persistence; (iv) Entrepreneurial knowledge; (v) Confidence in establishing a venture; (vi) Intension and desire towards creativity and innovation; (vii) Ability to manage and minimize risk; (viii) Responsiveness to opportunities (ix) Leadership and strategic decision making at right time.

These factors can be induced to the students by encouraging and making them develop a mini-project during their $2 \mathrm{nd}$ and $3 \mathrm{rd}$ year of engineering. By developing some simple mini-projects which can solve some simple realistic problems, students can gain the characteristics of being an entrepreneur which further gives them more confidence to become an entrepreneur.

In recent decades, there are great opportunities and challenges that continue to require engineers to literally invent the future by developing breakthrough technologies that solve global problems and enhance the quality of life. Hence there is a great demand for engineers to become entrepreneurs.

Innovation is required to address pressing problems and to maintain global competitiveness. Engineering is the foundation of much of that innovation. In this competitive world, teamwork, learning ability and soft skills along with academic excellence are very much needed for the career growth of a student. In the global work culture, engineering graduates have to work in groups. In order to be prepared to enter the workforce and thrive in this ever changing global economy, engineers need to be able to collaborate effectively as leaders, in teams, and with their peers. In addition to their technical and analytical expertise, they need to be flexible, resilient, creative, empathetic, and have the ability to recognize and seize opportunities. All of these skills should be taught to engineers as part of their formal education. It is thus the responsibility of engineering educators to in still these qualities in students to enable them to be more innovative and entrepreneurial.

To prepare our students reach the drastically changing technology, conventional means of teaching and learning methods should be kept aside and new innovative ways should come up and faculty should get transformed from teacher to facilitator. Hence, it is the responsibility of the institute to think about the introduction and redesigning of latest teaching and learning techniques which best suit to this advanced technology.

For the present days, engineers need to be entrepreneurial in order to understand and contribute in the context of market and business pressures. For engineers who start companies soon after graduation, entrepreneurship education gives them solid experience in product design and development, prototyping, technology trends, and market analysis. These skills are just as relevant for success in established enterprises as they are in start-ups; students with entrepreneurial training who join established firms are better prepared to become effective team members and managers and can better support their employers as innovators.

By introducing the entrepreneurship as course in engineering program students can gain the knowledge and attitudes that are required to identify opportunities and bring them to life. Students who take part in entrepreneurship programs as undergraduates gain insights such as understanding and designing for end users ("empathy"), working in and managing interdisciplinary teams, communicating effectively, thinking critically, understanding business basics, and solving open-ended problems [9].

The integration of entrepreneurship and innovation in engineering education will require a shift in thinking and willingness on the part of faculty to participate in, or at least accept changes in the engineering curriculum. Recent experiences in introducing new approaches to engineering education are a good indicator of the challenges and a guide to which approaches will be effective.

The increase in demand for the quality of engineering graduates gave a major influence on the revision of the criteria for engineering programs by National Board of Accreditation (NBA). To get "International Recognition of

Educational Qualifications" as per Washington Accord, NBA put more emphasis and focuses on Outcome Based Education (OBE). Though India became a provisional member of the Washington 
Accord (WA) in the year 2007, it became signatory membership of Washington Accord in June 2014. The Washington Accord is an international agreement among bodies responsible for accrediting engineering degree programmes. In this context, National Board of Accreditation (NBA) should now seriously look for the transformation of engineering education to the global standard by adopting Outcome Based Education(OBE).

The new accreditation approach shifts emphasis away from "what is being taught" to "what is being learned". To achieve this, traditional education was transformed to "Outcome Based Education". Outcome-based education, as defined by Spady is "a way of designing, developing, delivering and documenting instruction in terms of its intended goals and outcomes". "Exit outcomes are a critical factor, in designing the curriculum", Spady suggests. "You develop the curriculum from the outcomes you want students to demonstrate, rather than writing objectives for the curriculum you already have".

Engineering programs are now required to demonstrate that their graduates are achieving a set of specified learning outcomes. One such learning outcome is to give more emphasis on developing entrepreneurial skills which leads to the production of more number of entrepreneurs. In that context, preparing our graduates to become entrepreneurs is considered to be one of the agenda of any engineering institute.

\section{Method of Promoting Students to Become Entrepreneurs}

Cultivating entrepreneurial thinking in students requires learning through practice by going beyond teaching fundamentals and reviewing case studies. There are many professional bodies that support engineering students to actively involve and engage in entrepreneurial programs. One such body is a Leadership, Entrepreneurship, and Professional Development (LEAD) student chapter model proposed by the IEEE Computer Society, through its Educational Activity Board's Committee of Diversity and External Activities (CDEA). The goal of IEEECS LEAD student chapters is to introduce students in various activities that promote entrepreneurial thinking and facilitate critical hands-on experiences that can induce the excitement of discovery and develop the professional skills needed for successful computing careers.
Although engineers often have experience working with teams, most of them lack entrepreneurial skills, which can be acquired through education and training. Entrepreneurship courses in engineering and computing programs are mostly theoretical in nature and often lack the practical insights that can only be achieved through extracurricular opportunities to develop and implement ideas in actual situations. Institutions must therefore commit to offer a campus environment that supports entrepreneurial activities. Such activities let students experience the full innovation process, empower them with the excitement of discovery, and educate them in entrepreneurship fundamentals. IEEE-CS LEAD student chapter will immerse students in entrepreneurship experiences through virtual and face-to-face interactions with highly recognized and qualified experts.

The National Entrepreneurship Network (NEN) is Wadhwani Foundations flagship initiative in India. It was established in 2003 with a mission to inspire, educate and support high potential entrepreneurs while driving entrepreneurship as a catalyst to create millions of high-value jobs. NEN does this by building institutional capacity for entrepreneur support and a robust entrepreneurial eco-system.

The objective of NEN is to - build institutional capacity for creating entrepreneurs; develop and inspire a pool of aspiring entrepreneurs at academic institutes; enable access to leadership and skillsbuilding programs; provide access to expert, mentor and capital networks. NEN also strengthen the entrepreneurial eco-system to support existing startups, increasing entrepreneurs' access to strategic mentoring; skills-building programs.

\section{Results and Discussion}

Entrepreneurship education motivates towards venture creation. Intension of creating a venture can be increased by providing a proper entrepreneurship education. In this paper, we have presented two case studies taken up by a set of students and demonstrated how students have used entrepreneurial and innovative skills to develop software solutions for the mini-projects. From this study it is observed that by introducing the concept of mini-project, at least a couple of students can become successful entrepreneurs in future.

\section{A. Case Study of Budding Entrepreneurs - "CROSS-}




\section{OVER GAMING STUDIOS":}

"CROSS - OVER Gaming Studios" is an Independent Video Game Development Entrepreneurial team established at P.E.S. College of Engineering, Mandya, which is expected to be legalized as a fully-fledged 'Company' shortly.

The primary aim of this team is to find the hidden talents in those dedicated young students and to extract that talent to create a work of art that can be enjoyed by one and all. The team was launched during the event of 'CRESCO 13.0 - A State Level Technical Symposium' organized by 'IEEE - PESCE' in which the team featured its First Non-Commercial Product 'Amazono'. The product was showcased in CRESCO 13.0, which attracted the highest gathering of students all over the state and hence it was awarded "The Best Event in IEEE - PESCE CRESCO-13.0".

This team is dedicated to bring out the next level of gaming experience, yet to be discovered by all the Gamers across the world. It is now developing the next Massive Game called 'War Souls'. The demo is expected to be released by the end of 2015. This team was formed jointly by Mr. Arka Deb, Mr. Arjun M Y, Ms. Noor AfshanFathima, Mr. Aju Antony and Mr. Abhijit Pai, out of interest during their First year of Bachelor of Engineering at P.E.S College of Engineering, Mandya. Later, it was followed by 15 interested, highly enthusiastic and trained students of PESCE, Mandya. The goal of these creative, likeminded young entrepreneurs is to craft a remark in the world by building a successful company in the name "Cross Over Gaming Studios".

B. Case study to demontrate innovation to solve realistic problem:

In this paper we have illustrated another case study which demonstrates the technical skills and innovative ideas of our students applied to solve realistic problem. As a case study, a software solution developed by our students to solve a problem useful for police department is presented in this paper.

A brief summary of the problem: Unclaimed vehicles with lots of dust and rust on them are a common sight in police station premises throughout India. Such unclaimed vehicles comprises of Vehicles involved in crime and seized by police; Vehicles involved in accident cases and seized by police; Stolen vehicles recovered by police from thieves and Vehicles abandoned by thieves or by drunkards.

Many such vehicles that are involved in crime and accident are not claimed back by owners because in most of the cases they do not have legitimate documents to prove their ownership. This is because some vehicles are stolen vehicles which are purchased without any documentation at cheap rates. Also, stolen vehicles that have been recovered by police from thieves lie in police stations. After recovery of vehicles some officers show less interest to know whether that vehicle is returned to the owner or not. In addition, the details of the vehicles should be sent to the RTO to know the owner of vehicle through Registration Certificate (RC) book details. But this process takes lot of time and most of the times the RC book would not have been updated with the correct owner as the vehicle might have been bought and sold by 3 to 4 owners. So it becomes difficult to track the last owner. According to the statistics collected from 30 police stations in Mandya district, there were more than 1700 unclaimed vehicles. A snapshot of unclaimed vehicles lying in Mandya police department is shown in Figure 1. This shows that such unclaimed vehicles lying in police stations are a perennial problem throughout India. To tackle with this problem, Superintendent of Police of Mandya District Shri BhushanGulabraoBorase had approached the Head of the Department of Computer Science and Engineering, PES College of Engineering, Mandya. So, this problem was given as project to three deserved final year students Navneeth N, Nithin H N and Yashvant N, under the guidance of Dr. M. C. Padma, Professor and Head of Computer Science and Engineering department, PES College of Engineering, Mandya. They developed a software which could solve the problem raised by the police community.

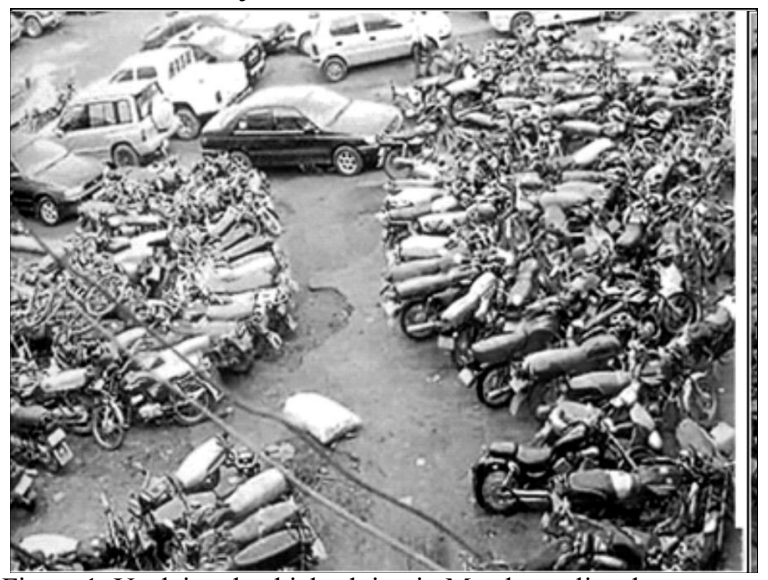

Figure 1. Unclaimed vehicles lying in Mandya police department 
A brief summary of the Software project: Three databases have been developed and used in this project to trace the unclaimed vehicle to its owner: (1) Data of unclaimed vehicles lying in police stations which includes information like registration number, engine number, chassis number, make and model of the vehicle. (2) Data of all the stolen vehicles of Karnataka state. This data was taken from a program of National Crime Record Bureau (NCRB) called motor vehicle verification counter that is available in each district in Superintend of Police (SP) office of Karnataka. (3) Data of all registered vehicles in all Regional Transport Office (RTO) across India. This data was accessed by getting username and password of the website vahan.nic.in.

The software allows data entry of unclaimed vehicles at police station level. It allows update of stolen vehicles every month and it automatically matches the unclaimed vehicles data with the stolen vehicles data. That means, the databases were matched for common value and results were obtained in the format showing in which police station the complaint was received for the stolen vehicle "XYZ" and in which police station that vehicle was lying unclaimed. For those vehicles in which First Information Report (FIR) could not be traced, the owner was traced with the help of website vahan.nic.in. Thus the software gives result in different user friendly formats. Many vehicles stolen in Hassan, Mysore, Bangalore etc. were lying unclaimed in Mandya Police stations. This software is being successfully used in Mandya District and it is expected to extend it in Southern Range, at State level and also at National level.

The results were an eye opener. Vehicle stolen in one of the police station limits of Mandya District was lying unclaimed in another police station of same Mandya district for years. Similarly many vehicles stolen in neighboring districts have been found lying unclaimed in Mandya District police stations. As on July 2015 about 736 vehicles have been traced and handed over to the legitimate owner fromMandya district. A snapshot of unclaimed vehicles traced and handed over to the legitimate owner in Mandya police department is shown in Figure 2. If the unclaimed vehicle data of entire state is fed into the software, then the result will be even bigger. The software developed can be extended for the entire state and even National level too. This project results in legitimate owner getting back his vehicle and the police stations getting cleaner. It is a big step towards improving appearance of police stations and major contribution to Swachh BharatMission.

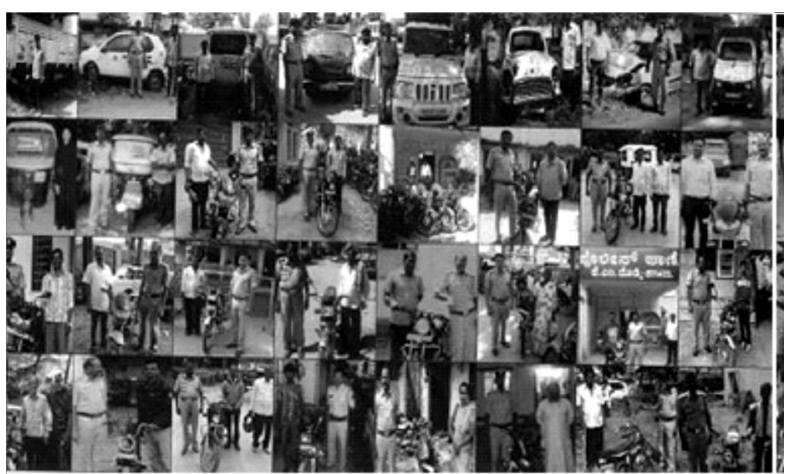

Figure 2. Unclaimed vehicles traced and handed over to the legitimate owner in Mandya police department.

This project was presented in a technical competition "Infosys Project Innovation Challenge 2014" organized by Infosys, Mysore on 21 st- May-14, by Navneeth $\mathrm{N}$, Nithin $\mathrm{H} \mathrm{N}$, Yashvant $\mathrm{N}$ and the project was awarded second prize. It has been appreciated by the Principal and all faculty members of the PES College of Engineering. Superintendent of Police Shri BhushanGulabraoBorase, Mandya District also appreciated this work.

PES College of Engineering has been in Association with the Police Department of Mandya to tackle a number of problems in scientific way. To name few such cases, Dr.H.V.Ravindra and his team from the Department of Mechanical Engineering had given suggestions for ways and means to prevent Bullock Cart accidents on Highways. Civil Engineering Department has worked on traffic congestion problem to reduce traffic in Mandya City under guidance of Dr.S.P.Mahendra.

In order to motivate and strengthen confidence to our students to become entrepreneurs, we should assign these types of realistic problems as a mini project for a group of students during their 2 nd and 3 rd year. Students involved in developing such projects will definitely gain technical competencies, practical knowledge, leadership quality and confidence to become leaders or entrepreneurs. From this paper, it is observed that adopting mini project based learning is considered to be the best pedagogical method to encourage our students to become entrepreneurs.

Introducing mini-project to encourgae entrepreneurship 
Introducing mini-project in the engineering curriculum to encourage entrepreneurship has many benefits. However, the implementation remains a challenging task for both faculty and students. Hopefully, some of the experiences shared in this paper will support and encourage others to facilitate the integration of these activities in their undergraduate engineering curriculum. Particularly autonomous colleges can best utilize the autonomy by redesigning the curriculum by incorporating this type of mini-project scheme for 2nd and 3rd year. Normally, the strength of undergraduate students is quite large ranging from 60 to 120 . However, out of 120 students in a year, it is satisfactory if at least 20-30 students are showing interest and focusing on to become entrepreneurs. In addition, it is the responsibility of the institutions to support in establishing NEN cell which gives a best platform for the students to showcase their hidden talents and start small ventures. The institute should encourage and recognize such talented students by awarding and providing financial support through TEQIP funds.

\section{Conclusion}

The modern engineering profession requires skills and technical competencies. Also, our engineering students must acquire lifelong learning to be able to apply their knowledge in accordance with the new problems faced in their daily life. Hence, it is anticipated to introduce a course on entrepreneurship and a mini-project in 2 nd and 3 rd year. This provides a best platform for the students to gain greater depth of understanding the concepts, broader knowledge base, improved communication and interpersonal/social skills, enhanced leadership skills, increased creativity, and improved writing skills. In this paper, the experience of introducing mini project in the engineering curriculum to encourage entrepreneurship is reported. Learning through the development of mini-project can be considered an extremely effective method that empowers students to learn both the fundamental concepts and principles and, to develop an understanding of how they have utilized in applied engineering to solve design problems.

\section{References}

[1] Berglund, H. and Wennberg, K, 'Creativity among entrepreneurship students: comparing engineering and business education', Int. J. Continuing Engineering Education and Lifelong Learning, Vol. 16, No. 5, 2006, pp.366-379.
[2] Duval-Couetil N, Reed-Rhoads T, Haghighi S. 2012. Engineering students and entrepreneurship education: Involvement, attitudes and outcomes. International Journal of Engineering Education 28(2):425-435.

[3] Nathalie Duval-Couetil, Teri Reed-Rhoads, and Shiva Haghighi, "The Engineering Entrepreneurship Survey: An Assessment Instrument to Examine Engineering Student Involvement in Entrepreneurship Education", Volume 2, Number 2, Special Issue 2011, The Journal of Engineering Entrepreneurship, pp 3556.

[4] Besterfield-Sacre M, Ozaltin NO, Shartrand A, Shuman LJ, Weilerstein P. 2011. Understanding the technical entrepreneurship landscape in engineering education (AC 2011-1729). Presented at the 2011 Annual Conference and Exposition of the American Society for Engineering Education (ASEE), June 26-29, Vancouver BC.

[5] Brooks R, Green WS, Hubbard RG, Jain D, Katehi L, McLendon G, Plummer J, Roomkin M. 2007. Entrepreneurship in American Higher Education. Report from the Kauffman Panel on Entrepreneurship Curriculum in Higher Education.

[6] Al Romaih, Nasser; M. Rajai \& S.J. Gandhi, "An Innovative Approach to Educating Engineers in Entrepreneurship," Proceedings of The 2013 American Society for Engineering Education, Pacific Southwest Conference, Pomona, CA, April 18-20, 2013.

[7] Goldstein, M. (2013), "Engineering Entrepreneurship Education Climate and Current Trends: A Literature Synthesis," White Paper at Purdue University, pp. 2-11.

[8] Hall, Alan, "To Succeed as an Entrepreneur, Know Your Customer," Forbes Magazine, June 14, 2012, http:/www.forbes.com/sites/alanhall/2012/06/14/ to-succeed-as-an-entrepreneur-know-yourcustomer/; Accessed on January 2, 2013.

[9] Goldstein, M. (2013), "Engineering Entrepreneurship Education Climate and Current Trends: A Literature Synthesis," White Paper at Purdue University, pp. 2-11. 